\title{
Uptake, assimilation and toxicity of cyanogenic compounds in plants: facts and fiction
}

\author{
X.-Z. Yu
}

Received: 21 October 2013/Revised: 20 January 2014/Accepted: 17 March 2014/Published online: 10 April 2014

(C) Islamic Azad University (IAU) 2014

\begin{abstract}
Cyanide is a simple nitrogenous compound that arises from both anthropogenic and natural sources. Plants vary considerably in their physiological and biochemical responses to different species of exogenous cyanides from reduced growth to inhibition on enzymatic activities. Also, great differences in uptake, assimilation and toxicity between free cyanide and iron cyanide have been observed. Unlike botanical uptake of free cyanide chiefly achieved by simple diffusion, iron cyanides have long been considered membrane impermeable and a protein-mediated uptake mode has been proposed. Biological fate of cyanides in plant materials is highly dependent on speciation of cyanides present. Natural development of degradation of free cyanide in plants is very obvious, where the $\beta$-cyanoalanine pathway has been widely distributed in higher plants and the production of asparagine and aspartate associated with cyanide assimilation is suggestive. Because phytodissociation of iron cyanides into free cyanide in plant materials is not a mandatory process involved in phytoassimilation, plants probably metabolized them through an undiscovered degradation pathway rather than the $\beta$-cyanoalanine pathway. Available information shows phytoassimilation of endogenous cyanide into nitrogen metabolism; however, additional efforts to fully elucidate presence of essential enzymes involved and their proteomic or DNA expression quantitatively are needed to prove and clarify phyto-benefits of assimilation of exogenous cyanide in plant nutrition.
\end{abstract}

\footnotetext{
X.-Z. Yu ( $\square)$

The Guangxi Key Laboratory of Theory and Technology for Environmental Pollution Control, College of Environmental Science and Engineering, Guilin University of Technology, Guilin 541004, People's Republic of China e-mail: yuxiaozhang@hotmail.com
}

Keywords Biotransformation - Cyanide - Iron cyanide Toxicity $\cdot$ Plant $\cdot$ Transport

\section{Introduction}

There are several types of cyanogenic compounds frequently detected in the environment, namely free cyanide, weak-acid dissociable cyanide, stable complexes, thiocyanate and nitriles (Kjeldsen 1999; Ebbs et al. 2008). However, free cyanide is a chemical with a bad reputation to the public as a fast-acting, highly toxic substance, especially used in gas chamber in the World War II Holocaust, in capital punishment with death sentences (Trapp and Christiansen 2003). Stability and fate of cyanogenic compounds in ambient environment appear to be related to numerous biotic and abiotic factors, e.g., biological activity and community, $\mathrm{pH}$, redox potential, availability and quality of solar radiation, and presence of organic acids as well (Meeussen et al. 1995; Rennert and Mansfeldt 2002; Ghosh et al. 2004) changes in physicochemical conditions in the environment that will alter speciation and mobility of cyanides (Zagury et al. 2004; Ebbs et al. 2008). It is well known that dynamic interconversion among these species of cyanides in soils and sediments is most likely (Meeussen et al. 1992; Theis et al. 1994).

Although cyanogenic compounds occur naturally in certain bacteria, fungi, algae and higher plants (WongChong et al. 2006), the most significant natural source of free cyanide in the environment is from hydrolysis of cyanogenic glycosides in higher plants (Halkier et al. 1988; Lechtenberg and Nahrstedt 1999; Vetter 2000; Zagrobelny et al. 2004). Naturally occurring free cyanide is typically maintained at very low levels, such as in soy protein products, free cyanide usually ranges from 0.07 to $0.30 \mathrm{mg}$ 
CN/kg FW (Poulton 1990; Wong-Chong et al. 2006). However, anthropogenic inputs of cyanide to the environment are greater in amounts and intensity than natural production. Cyanide is a commercial commodity and widely used in a range of products, e.g., nylon, adhesives, computer electronics, cosmetics, dyes, pharmaceuticals and road salts that have benefited our society (Korte et al. 2000; Mudder and Botz 2001). It can also be used directly in a variety of processes, including electroplating and hydrometallurgical gold or silver extraction (Boening and Chew 1999; Srivastava and Duvvuru Muni 2010). The extensive use of cyanide-containing chemicals results in a significant release of cyanide into the environment on a continuous basis (Zheng et al. 2004; Donato et al. 2007). For example, the open tailing ponds stored effluents generated from extraction process of gold mining operation contain up to $120 \mathrm{mg} / \mathrm{L}$ free cyanide to $400 \mathrm{mg} / \mathrm{L}$ total cyanide, including various iron cyanides with heavy metals (Ebel et al. 2007). It also has been reported that there are about 3,000 and 1,000 manufactured gas plant facilities in the USA and in Germany (Rennert and Mansfeldt 2002). Therefore, the risks derived from the unregulated disposal of industrial effluents have engendered widespread concern. Indeed, cyanide has been among the top 30 chemicals on the US CERCLA (The Comprehensive Environmental Response, Compensation and Liability Act) Priority List of Hazardous Substances since 1995 (Ebbs et al. 2003). It has been reported that cyanide has increased ecological risk of soil, sediment, surface water, and groundwater and become an environmental, health, economic and planning issue worldwide (Boening and Chew 1999).

Different engineering efforts have been developed to clean up cyanide contamination through a destructionbased process (White et al. 2000; Yngard et al. 2007). However, in most cases, they are either noneffective or heavy disturbance to ecosystems. In response to growing public and political concern to health and safety of the environment, biology-emerging approaches have been developed. Although iron cyanides are quite recalcitrant against microbial and fungal biodegradation (Ghosh et al. 1999; Meeussen et al. 1992), a broad range of bacteria and fungi has been isolated to have appropriate enzyme systems induced for degrading cyanogenic compounds (Ebbs 2004). The similar shortcoming of time-consuming also arises in bioremediation of free cyanide. Phytoremediation, in contrast to other biology-based methods, has received considerable attention in remediating sites polluted with low to moderate levels of contamination (Akguc et al. 2010; Cheng et al. 2011; Ling et al. 2011; Dubey and Shiwani 2012; Sreekanth et al. 2013). As a natural, pumpand-treat system, phytoremediation is one of the very few technologies that can address a diverse range of media and contaminants simultaneously (Kord et al. 2010; Ashraf et al. 2011; Hegazy et al. 2011; Dede et al. 2012; Parween et al. 2012; Karimi et al. 2013). Indeed, a number of plants from three continents and climate zones have been identified to transport and assimilate free cyanide and iron cyanides, and capability highly relies on their genetic traits of plants (Ebbs et al. 2003; Yu et al. 2004; Larsen et al. 2005; Ebel et al. 2007). This review discusses uptake, assimilation and toxicity of the most important cyanogenic compounds in plants. Particular attention will be given to possible mechanisms involved in phyto-assimilation of cyanogenic compounds.

\section{Phytotoxicity of cyanogenic compounds}

An understanding of toxicity of cyanogenic compounds is critical for assessing risk associated with these chemicals (Kjeldsen 1999). Cyanide refers to all of cyanide compounds containing a triple-bonded carbon nitrogen functional group. Most such compounds are highly toxic, carcinogenic and mutagenic (Banerjee et al. 2002). It is obvious that free cyanide in biota can disrupt numerous metabolic processes (Ebbs et al. 2003), principally by binding to iron, copper and sulfur-containing enzymes and proteins required for oxygen transportation to cells (Schnepp 2006; Barillo 2009). It can also react with biota functional groups such as carbonyls or disulfide bonds (Ebbs et al. 2006). Common symptoms of cyanide poisoning include gastric problems, vomiting, respiratory distress, convulsions and coma (Banerjee et al. 2002). It is known that free cyanide can readily block mitochondrial electron transport system via complexation with iron in terminal cytochrome (Cooper and Brown 2008). Cyanide is the most detrimental inhibitor to poison the respiratory system by inhibiting final transport of electrons, and preventing production of ATP (Schnepp 2006; Srivastava and Duvvuru Muni 2010), which causes an anesthetized state through the pentose phosphate pathway and dysfunctions of cardiovascular and central nervous systems consequently leads to cell death (Ebbs et al. 2006; Donato et al. 2007; Barillo 2009).

The impact of cyanogenic compounds in physiology of plants largely related to the types of cyanides bioavailable, which are responsible for their uptake, transport and resultant toxicity in plant systems. Indeed, phytotoxicity of cyanides has been observed at multiple levels, from reduced growth rate, through effects on biomass, transpiration rate and chlorophyll content, to inhibition on enzymatic activities (Larsen et al. 2005; Yu et al. 2005a, 2007, 
2008; Yu and Gu 2009). It has been proposed that the possible mechanism involved in phytotoxicity of cyanide is generally ascribed to formation of complexes with metal ions in the enzyme cytochrome oxidase (Solmonson 1981). A mitochondrial alternative oxidase capable of transferring electrons from the ATP pool to oxygen has been isolated in plants in response to cyanide exposure (Siedow and Umbach 1995; Wagner and Krab 1995). Although not associated with cyanide assimilation, this alternative oxidase does contribute to plant's abilities to resist cyanide toxicity (Ebbs et al. 2006). The $\mathrm{EC}_{50^{-}} 7$ days values inhibiting the reproduction of $C$. dubia by $50 \%$ were 98,194 and $216 \mu \mathrm{g}$ $\mathrm{CN} / \mathrm{L}$ for $\mathrm{KCN}, \mathrm{K}_{3} \mathrm{Fe}(\mathrm{CN})_{6}$ and $\mathrm{K}_{4} \mathrm{Fe}(\mathrm{CN})_{6}$, respectively (Manar et al. 2011), where $\mathrm{EC}_{50}-3 \mathrm{~d}$ was determined to be $57 \mu \mathrm{g} \mathrm{CN} / \mathrm{L}$ for $N$. closterium inhibiting $50 \%$ of the population growth (Pablo et al. 1997). It is evident that aquatic vascular plants are more resistant to cyanide than algae (Eisler and Wiemeyer 2004). For instance, external cyanide concentrations of $26 \mu \mathrm{g} \mathrm{CN} / \mathrm{L}$ are considered nontoxic for mouse-ear cress (Arabidopsis thaliana) (McMahon-Smith and Arteca 2000). A pronounced wilting after a 3-days exposure to $25 \mathrm{mg} \mathrm{NaCN} / \mathrm{kg}$ soil (DW) has been observed in bush bean (Phaseolus vulgaris L.), while addition of $100 \mathrm{mg} \mathrm{NaCN} / \mathrm{kg}$ causes significant reduction in growth, with $100 \%$ mortality after 9 days (Wallace et al. 1977). Levels of $2 \mathrm{mg} \mathrm{CN} / \mathrm{L}$ in hydroponic solution are toxic to willows (Salix viminalis) with a $50 \%$ depression in transpiration after 72-h exposure, while levels $\geq 20 \mathrm{mg} \mathrm{CN} / \mathrm{L}$ are immediately lethal (Larsen et al. 2004). $\mathrm{EC}_{50}$ values for weeping willows (Salix babylonica L.) were estimated to be between 3.27 and $8.23 \mathrm{mg} \mathrm{CN} / \mathrm{L}$ using normalized transpiration rate as a sensitive endpoint for toxicity determination (Yu et al. 2005a). In contrast, no negative influence on transpiration and growth of diamond willow (Salix eriocephala var. Michaux) exposed to $2 \mathrm{mg}$ $\mathrm{CN} / \mathrm{L}$ has been found after 20-d exposure (Ebbs et al. 2003). Sorghum (Sorghum bicolor) grown in soil and irrigated with solutions of 20 and $50 \mathrm{mg} \mathrm{CN} / \mathrm{L}$ reveals no toxic signs but increases the transpiration (Trapp et al. 2003). When exposed to cyanide equal to or $<4.74 \mathrm{mg} \mathrm{CN} /$ $\mathrm{L}$, weeping willows (S. babylonica L.) show positive growth, and soluble proteins in leaves are the most sensitive indicator to free cyanide application than other parameters selected (Yu et al. 2007).

It is obvious that plants can tolerate much higher concentrations of iron cyanides than free cyanide; however, phytotoxic mechanism of iron cyanides is still nondescribed clearly (Trapp and Christiansen 2003; Ebbs et al. 2003; Yu et al. 2008; Yu and Gu 2009). No toxic signs on basket willows (S. viminalis) exposed to ferro- or ferri- cyanide at $10 \mathrm{mg} \mathrm{CN} / \mathrm{L}$ have been found (Larsen and Trapp 2006). A similar result has been reported in the study of Samiotakis and Ebbs (2004), where barley, oat and wild cane allow for exposure of up to $50 \mathrm{mg}$ ferro-cyanide/L without adverse effects. In contrast, introduction of $8 \mathrm{mg} / \mathrm{L}$ ferro-cyanide into hydroponic nutrient solution results in decreases in water use, biomass and leaf area (Ebbs et al. 2006). Weeping willows (S. babylonica L.) have showed different responses to iron cyanides (Yu et al. 2008; Yu and Gu 2009), where POD activities and soluble protein content in leaves were noted the most sensitive indicator for plants exposed ferro- and ferri-cyanide, respectively.

At concentrations of $5.4 \mathrm{mg} \mathrm{CN} / \mathrm{L}$, Prussian blue does not cause any phytotoxic effects on balsam poplars (Populus trichocarpa $\mathrm{L}$.), while concentrations of $27 \mathrm{mg} \mathrm{CN} / \mathrm{L}$ slightly decrease transpiration. Balsam poplars are able to survive when grown in hydroponic solutions spiked with Prussian blue of up to $1,350 \mathrm{mg} \mathrm{CN} / \mathrm{L}$, although transpiration and growth of plants are significantly reduced (Larsen et al. 2005; Kang et al. 2007). Free cyanide reacts with various forms of sulfur to form thiocyanate in plant materials, which is relatively nontoxic (Kjeldsen 1999). Wheat (Triticum aestivum L.) irrigated with ammonium thiocyanate at a rate of $900 \mathrm{~kg} / \mathrm{ha}$ does not show any toxic symptoms and expressed a stimulation of growth after 69-d irrigation (Bissey and Bulter 1934; Ebbs et al. 2006). At similar doses of thiocyanate, ammonium thiocyanate caused more severe stress to rice seedlings (Oryza sativa $\mathrm{L}$. cv. XZX 45) than potassium thiocyanate, judged by transpiration rate and biomass growth rate (Yu et al. 2012a). In a recent work, metabolic responses of potassium thiocyanate in rice seedlings have been investigated, in which SCN-induced phytotoxicity appeared to be more sensitive to activities of POD in shoots and APX activities in roots than others (Yu and Zhang 2013). Additionally, among fifteen free amino acids detected, serine (Ser), proline (Pro) and methionine (Met) increased, while asparagine (Asp) decreased with an increase in doses of $\mathrm{SCN}^{-}$supplied (Yu and Zhang 2013).

\section{Uptake and biotransformation of cyanogenic compounds by plants}

Chemicals in solution can move into plants through either mass flow with water (advection) or diffusive flux (Bushey et al. 2006a), which is closely related to their chemical properties, speciation, concentrations of solutes and transpiration rate of plants (Burken and Schnoor 1997). If uptake is operated with advection, the process is usually 
described by transpiration stream concentration factor (TSCF), a proportionality constant relating to chemical partitioning between transpiration stream and water solution (Briggs et al. 1987; Burken and Schnoor 1998; Larsen et al. 2005). If uptake is controlled through diffusive flux, this mechanism may be described by Fick's first law (Larsen et al. 2005). Uptake by diffusion is largely related to permeability and surface area of roots (Trapp et al. 1994; Larsen et al. 2005). After entering into roots, the biological fate of chemicals in plant materials is largely controlled by chemical properties and concentrations of solutes. Solutes can remain unchanged; become to bound a ligand; or be modified by detoxification, degradation or assimilation (Bushey et al. 2006a). When levels of solutes accumulated in plant materials are below toxicity threshold, plants are able to maintain their normal functioning. However, if velocity of assimilation of solutes is slower than that accumulated in plants, phytotoxic effects appear (Larsen et al. 2005).

Uptake and transport of cyanide by plants

The first interaction between cyanide and plants is during its uptake process. In spite of capabilities of plants to take up both species of free cyanide and iron cyanides readily, great differences in the uptake pathway between these species have been observed (Larsen et al. 2004, 2005; Yu et al. 2005a, b, 2007, 2008; Yu and Gu 2009). Unlike botanical uptake of heavy metals fitting to the saturation kinetics, which is typically used to represent proteinmediated uptake mode (Cohen et al. 1998), free cyanide behaves differently from heavy metals and requires different strategies. The $\mathrm{p} K_{\mathrm{a}}$ for $\mathrm{HCN}$ dissociation equilibrium is 9.24. $\mathrm{CN}^{-}$is the dominant species in solution under alkaline conditions ( $\mathrm{pH}>9.24)$, while the aqueous form of $\mathrm{HCN}$ predominates at lower $\mathrm{pH}$ levels. Due to the size and negative charge of molecule, electrochemical gradient favors a higher concentration of $\mathrm{CN}^{-}$exterior to cell membrane relative to cell interior (Bushey et al. 2006a). However, as a neutral species, HCN present in plant-water system can diffuse through cell membrane, particularly as a low molecular weight organic molecule (Bushey et al. 2006a, b), and the uptake velocity is independent upon the presence of exogenous inhibitors ( $\mathrm{Yu}$ et al. 2011a). Additionally, diffusive and advective mass transfer from the plant-water system does not sufficiently account for plantmediated uptake of free cyanide because metabolic processes of free cyanide in plant tissues are highly activated in phytoremoval of free cyanide and may regulate and/or limit movement of cyanide species into vascular bundle at the endodermis (Bushey et al. 2006a, b). Indeed, 28 of Chinese vegetation plants belonging to 23 families have been appraised for their capacities for removal of free cyanide, in which all plant species have been found to be able to remove free cyanide efficiently, but with different phyto-removal rates (Yu et al. 2004). The fastest cyanide removal was by Chinese elder (Sambucus chinensis) with a removal capacity of $8.8 \mathrm{mg} \mathrm{CN} / \mathrm{kg} \mathrm{h}$, followed by upright hedge-parsley (Torilis japonica) with a value of $7.5 \mathrm{mg}$ $\mathrm{CN} / \mathrm{kg} \mathrm{h}$. The lowest removal capacity had the snow-pine tree (Credrus deodara (Roxb.) Loud). Ebbs et al. (2003) used free cyanide labeled with ${ }^{15} \mathrm{~N}$ to track its transport and fate in diamond willows (S. eriocephala L. var. Michaux). As expected, free cyanide was rapidly taken up by plants. Despite a significant enrichment in the ${ }^{15} \mathrm{~N}$ content of the plant materials, negligible cyanide was tracked in any part of the plant tissues, indicating that applied free cyanide was metabolized by plants. Larsen et al. (2004) determined the metabolic capacity of five Danish woody plants (willow, poplar, elder, rose and birch) for cyanide and found that the removal rates followed the Michaelis-Menten kinetics, where realistic values of the half-saturation constant, $K_{\mathrm{M}}$, were around $1.5 \mathrm{mg} \mathrm{CN} / \mathrm{L}$; the maximum metabolic capacity, $v_{\max }$, was between 9.3 and $14.5 \mathrm{mg} \mathrm{CN} / \mathrm{kg} \mathrm{FW} \mathrm{h}$. The Michaelis-Menten kinetics of cyanide removal was also determined for 12 Chinese plant species out of 9 families (Table 1), where values of $K_{\mathrm{M}}$ were found in a range between 0.90 and $3.15 \mathrm{mg} \mathrm{CN} / \mathrm{L}$, and the values of $v_{\max }$ were normally distributed with a mean of $13 \mathrm{mg} \mathrm{CN} /$ $\mathrm{kg} \mathrm{h}$ using nonlinear regression treatments ( $\mathrm{Yu}$ et al. 2005b). Additionally, differences in Michaelis-Menten kinetics for different cultivars of maize during cyanide removal were determined using the same exposure regime ( $\mathrm{Yu}$ and $\mathrm{Gu}$ 2007). A small variation in metabolic rates between the different cultivars was found, in which values of $v_{\max }$ and $K_{\mathrm{M}}$ were found to be $10.80-22.80 \mathrm{mg} \mathrm{CN} / \mathrm{kg} \mathrm{h}$ and 2.57-7.09 $\mathrm{mg} \mathrm{CN} / \mathrm{L}$ using nonlinear regression treatments, respectively. Ebel et al. (2007) also found that cyanide at 5.8 and $10 \mathrm{mg} / \mathrm{L}$ was completely eliminated by water hyacinth (Eichhornia crassipes) after 23-32 h. Metabolism of $\mathrm{K}^{14} \mathrm{CN}$ was measured in batch systems with leaf and root cuttings. Leaf cuttings removed about $40 \%$ of the radioactivity from solution after $28 \mathrm{~h}$ and $10 \%$ was converted to ${ }^{14} \mathrm{CO}_{2}$; root cuttings converted $25 \%$ into ${ }^{14} \mathrm{CO}_{2}$ after $48 \mathrm{~h}$ but only absorbed $12 \%$ in their tissues. The calculated $K_{\mathrm{M}}$ of the leaf cuttings was $12 \mathrm{mg} \mathrm{CN} / \mathrm{L}$, and the $v_{\max }$ was $35 \mathrm{mg} \mathrm{CN} / \mathrm{kg} \mathrm{FW} \mathrm{h.}$

Unlike botanical uptake of free cyanide chiefly achieved by simple diffusion (Dzombak et al. 2005), iron cyanides have long been considered membrane impermeable 
Table 1 Fitted Michaelis-Menten parameters $\left(v_{\max }\right.$ and $\left.K_{\mathrm{M}}\right)$ of cyanide removal by plant leaves

\begin{tabular}{|c|c|c|c|c|c|c|}
\hline \multirow[t]{2}{*}{ Species } & \multirow[t]{2}{*}{ Family } & \multicolumn{2}{|l|}{ Nonlinear fit } & \multicolumn{2}{|c|}{ Lineweaver-Burk } & \multirow{2}{*}{$\begin{array}{l}\text { Cyanogenic } \\
\text { family }\end{array}$} \\
\hline & & $\begin{array}{l}v_{\max } \\
(\mathrm{mg} \mathrm{CN} / \mathrm{kg} \mathrm{h})\end{array}$ & $\begin{array}{l}K_{\mathrm{M}} \\
(\mathrm{mg} \mathrm{CN} / \mathrm{L})\end{array}$ & $\begin{array}{l}v_{\max } \\
(\mathrm{mg} \mathrm{CN} / \mathrm{kg} \mathrm{h})\end{array}$ & $\begin{array}{l}K_{\mathrm{M}} \\
(\mathrm{mg} \mathrm{CN} / \mathrm{L})\end{array}$ & \\
\hline Sambucus chinensis Lindel & $\begin{array}{r}\text { Caprifoliaceae/ } \\
\text { Sambucaceae }\end{array}$ & 21.91 & 1.49 & 33.22 & 3.36 & Yes \\
\hline Torilis japonica (Houtt) DC & Apiaceae/Umbelliferae & 19.17 & 1.39 & 23.69 & 2.20 & Unknown \\
\hline Salix babylonica $\mathrm{L}$. & Salicaceae & 9.57 & 1.26 & 12.76 & 2.33 & Unknown \\
\hline Zea mays $\mathrm{L}$. & Poaceae & 9.48 & 0.90 & 10.83 & 1.32 & Yes \\
\hline Prunus pseudocerasus Lindl. & Rosaceae & 17.53 & 1.65 & 30.39 & 4.52 & Yes \\
\hline Liquidambar formosana Hance & Hamamelidaceae & 11.12 & 1.15 & 14.20 & 1.97 & Unknown \\
\hline Nymphea teragona & Nymphaceae & 16.93 & 3.15 & 20.88 & 4.59 & Unknown \\
\hline Euonymus alatus (Thunb) Sieb & Celastraceae & 10.18 & 1.66 & 19.12 & 4.86 & Unknown \\
\hline $\begin{array}{l}\text { Metasequoia glyptostroboides } \\
\text { Hu \& W.C. Cheng }\end{array}$ & Taxodiaceae & 12.30 & 1.05 & 13.37 & 1.33 & Unknown \\
\hline Prunus persica Selb & Rosaceae & 13.91 & 1.33 & 16.50 & 1.96 & Yes \\
\hline Salix matssudana $\times$ alba & Salicaceae & 6.68 & 1.66 & 6.17 & 1.41 & Unknown \\
\hline Populus deltoides Marsh & Salicaceae & 7.38 & 2.20 & 10.49 & 4.12 & Unknown \\
\hline Mean & & 13.0 & 1.60 & 17.6 & 2.83 & \\
\hline Standard deviation & & 4.67 & 0.56 & 7.85 & 1.31 & \\
\hline
\end{tabular}

Source: Data from Yu et al. (2005b)

(Federico and Giartosio 1983; Ebbs et al. 2003; Roustan and Sablayrolles 2003). Federico and Giartosio (1983) confirmed that the existence of a NADH-ferri-cyanide $\left(\mathrm{O}_{2}\right)$ electron transport system, located within the plasmalemma, links to active reduction of ferri-cyanide in maize (Zea mays L., var XL 342). A related study with blue mallee plants and membrane transport inhibitor of carbonyl cyanide $m$-chlorophenylhydrazone suggested ferro-cyanide uptake is mediated partly by $\mathrm{H}^{+}$-coupled symporters (Ebbs et al. 2008). Possible transport and metabolic mechanisms of ferro-cyanide by willows were described by a computer model, where a protein-mediated uptake mode was proposed, but passive transport was also possible (Bruneau et al. 2006). Larsen and Trapp (2006) provided evidence that ferro-cyanide transport was closely related to transpiration of willows. Although detailed botanical uptake pathway is understood poorly, one conclusive result is that phyto-removal of iron cyanides is evident (Ebbs et al. 2003; Samiotakis and Ebbs 2004; Larsen and Trapp 2006; Yu et al. 2008, 2011a; Yu and Gu 2009, 2010). It has been proposed that there are two possible pathways involved in botanical uptake of iron cyanides (Larsen and Trapp 2006; $\mathrm{Yu}$ and $\mathrm{Gu}$ 2010): (1) iron cyanides dissociate into iron $\left(\mathrm{Fe}^{3+} / \mathrm{Fe}^{2+}\right)$ and free cyanide $\left(\mathrm{CN}^{-}\right)$first, and then, both species are able to penetrate the root membrane through the defined transport pathways; (2) plants take $\mathrm{Fe}^{3+} / \mathrm{Fe}^{2+}$ and free cyanide $\left(\mathrm{CN}^{-}\right)$as a complex without liberation.

Obviously, changes in physicochemical conditions in the environment will affect and/or alter speciation of iron cyanides (Zagury et al. 2004; Yu et al. 2011b, 2012b). Indeed, decomposition of iron cyanides into free cyanide in soils in the absence of light was detected at $\mathrm{pH}$ of 3.8 and 4.2 , and the rate appears to be inversely related to $\mathrm{pH}$ of ambient environment, while the half-life of iron cyanides was estimated to be approximately 100 years at $\mathrm{pH}$ of 6.5 using a decomposition model (Meeussen et al. 1992). It is also experimentally confirmed that dissociation rate of ferri-cyanide is significantly higher than that of ferro-cyanide in the presence of light (Yu et al. 2011b). Additionally, graminaceous plants have evolved a specific mechanism to acquire Fe through a chelation-based strategy (Kim and Guerino 2007). Phytosiderophores, Fe-solubilizing compounds, excreted by the roots of graminaceous plants are metal chelators for Fe with a high affinity (Harada et al. 2007). It is known that the equilibrium constants $(\log K)$ are 45.61 and 52.63 for ferro- and ferri-cyanide, respectively (Meeussen et al. 1992), while the $\log K$ value of Fe-phytosiderophores is only 18.1 (Mino et al. 1983). Therefore, liberation of both chemicals is highly unlikely to occur in the solution, due to the presence 
of phytosiderophores excreted by roots of grass plants. Dissociation of both iron cyanides into free cyanide in hydroponic solution is negligible at $\mathrm{pH}>7.0$ in the absence of light, and cyanide in solution remained principally in forms of cyanide complexes before transport into plant roots (Yu et al. 2011b, 2012b). Another way commonly found in higher plants is a reduction-based pathway, in which $\mathrm{Fe}$ becomes more phytoavailable by reducing $\mathrm{Fe}^{3+}$ to the more soluble $\mathrm{Fe}^{2+}$ in the presence of $\mathrm{Fe}^{3+}$ reductase at root cell's plasma membrane (Kim and Guerino 2007). However, there is no literature available to proof this $\mathrm{Fe}$-acquisition process during phyto-assimilation of iron cyanides.

After entering the plant materials, distribution of cyanide in different parts of plant materials was largely dependent on the chemical species of cyanide present during phyto-transport. It is known that the fate of different species of cyanide in plants was quite different (Larsen et al. 2005; Larsen and Trapp 2006; Yu and Gu 2010; Yu et al. 2011b, 2013). Indeed, free cyanide is able to enzymatically degrade through the defined degradation pathways (described in "Assimilation of free cyanide" section), where phyto-degradation of iron cyanides is apparent, but the degradation pathway is still under investigation (discusses in "Biotransformation of iron cyanides" section). It has been observed that free cyanide did not accumulate in healthy plants (Larsen et al. 2005), and the distribution of cyanide in different parts of plant materials of rice seedlings was slightly different ( $\mathrm{Yu}$ et al. 2012c), indicating that plants are able to metabolize free cyanide readily during transport within plant tissues. However, significant amounts of cyanide detected as total cyanide were accumulated in plant materials of rice seedlings exposed to iron cyanides, in which roots were the major sink for cyanide accumulation rather than shoots (Yu et al. 2012c, d).

Assimilation of free cyanide

Endogenous sources of free cyanide have been widely observed in higher plants (Ebbs et al. 2010). It is a co- product of ethylene biosynthesis from 1-aminocyclopropane-1-carboxylic acid (Peiser et al. 1984). Hydrogen cyanide is also naturally released during the hydrolysis of cyanogenic glycosides (Halkier et al. 1988; Lechtenberg and Nahrstedt 1999; Vetter 2000; Zagrobelny et al. 2004). However, cyanide naturally produced does not accumulate in plant tissues (Goudey et al. 1989; Maruyama et al. 2001), since cyanide degradation capacity in plant materials is several orders of magnitude higher than that cyanide of production (Manning 1988). Although natural development of degradation of cyanide in plants is very obvious (Miller and Conn 1980), there is no general rule in the phyto-removal capacity of cyanide for both cyanogenic and noncyanogenic plants exposed to exogenous free cyanide (Yu et al. 2004). Indeed, S. chinensis (Chinese elder), stemming from a cyanogenic family, had the highest removal capacity, while Viburnum, stemming from a closely related family, showed a relatively low removal capacity (Yu et al. 2004). It has been reported that transformation and assimilation of free cyanide in plants are generally through the following three pathways: the betacyanoalanine, sulfur transferase and formamide hydrolyase pathway (Tomati et al. 1972; Chew 1973; Miller and Conn 1980; Shirai 1978).

\section{Beta-cyanoalanine pathway}

All vascular plants possess the enzyme $\beta$-cyanoalanine synthase, which is the principal enzyme to catalyze detoxification of free cyanide in their metabolism (Miller and Conn 1980; Castric et al. 1972). In the first metabolic step (Fig. 1), the enzyme $\beta$-cyanoalanine synthase (E.C. 4.4.1.9) synthesizes the products $\beta$-cyanoalanine and hydrogen sulfide from the precursors $\mathrm{HCN}$ and cysteine (Miller and Conn 1980; Maruyama et al. 2001). The subsequent step is mediated by an enzyme (E.C. 4.2.1.65) with both nitrilase and nitrile hydratase activity (Ebbs et al. 2010). The nitrilase activity results in the formation of asparagine, while the nitrile hydratase forms aspartate and ammonium (Piotrowski et al. 2001; Piotrowski and Volmer
Fig. 1 Metabolism of cyanide via the $\beta$-cyanoalanine pathway [adapted from Miller and Conn (1980), Maruyama et al. (2001), Ebbs et al. (2010) with modification]
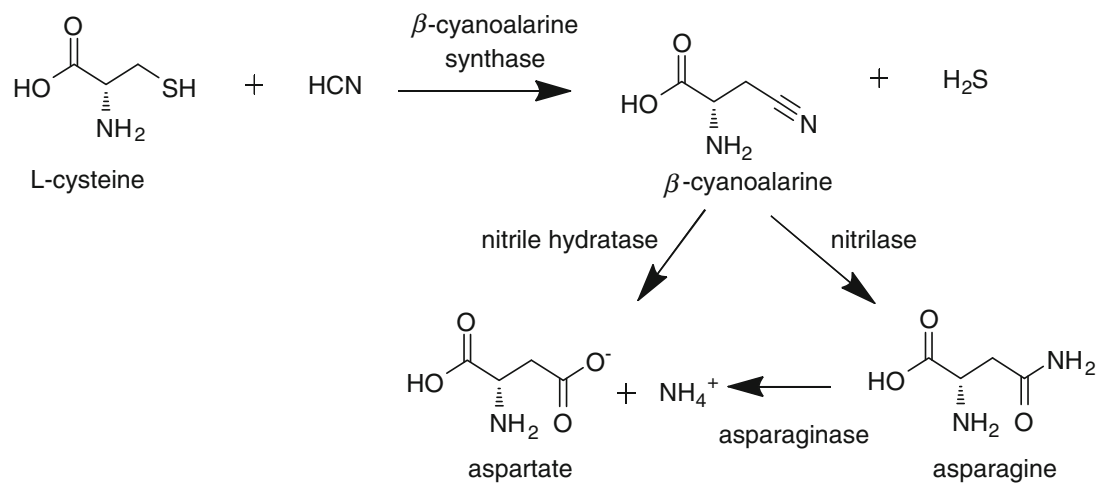


$$
\mathrm{CN}^{-}+\mathrm{S}_{2} \mathrm{O}_{3}^{2-} \stackrel{\text { rhodanese }}{\longrightarrow} \mathrm{SCN}^{-}+\mathrm{SO}_{3}{ }^{2-}
$$

Fig. 2 Metabolism of cyanide via the sulfur transferase pathway [adapted from Tomati et al. (1972), Chew (1973)]

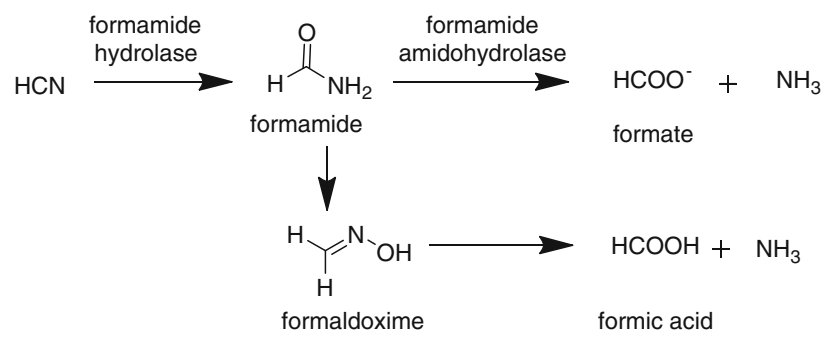

Fig. 3 Metabolism of cyanide via the formamide hydrolyase pathway [adapted from Shirai (1978), Miller and Conn (1980) with modification]

2006). Asparagine can be hydrolysed by the two subtypes of asparaginase (E.C. 3.5.1.1) to aspartate and ammonium (Bruneau et al. 2006; Lea et al. 2007).

\section{Rhodanese pathway}

The second pathway in plants for cyanide assimilation is through the sulfur transferase pathway (Fig. 2) catalyzed by a rhodanese enzyme (E.C. 2.8.1.1) in that cyanide is converted into thiocyanate $\left(\mathrm{SCN}^{-}\right)$, which is much less toxic than free cyanide (Tomati et al. 1972; Chew 1973). Although extensively investigated in animal sources and bacteria, rhodanese is a less common enzyme in higher plants (Tomati et al. 1972; Chew 1973; Miller and Conn 1980). In contrary, Shirai and Kurihara (1991) propose that rhodanese is generally distributed in plants, after testing rhodanese activity in 13 cyanogenic and 12 noncyanogenic plants.

\section{Formamide hydrolyase pathway}

It has been proposed that the third assimilatory pathway of free cyanide may exist in Japanese apricot (Pruns mume, Sieb et Zucc.) and loquats (Eriobotrya japonica L.) through the formamide hydrolyase pathway (Fig. 3), in which cyanide is first converted into formamide by formamide hydrolyase (FHL3-E.C. 4.2.1.66) and subsequently into formic acid and ammonia, with a possible intermediate formaldoxime. Another possible pathway is direct hydrolysis of formamide to formate and ammonia in the presence of the enzyme formamide amidohydrolase (Shirai 1978; Miller and Conn 1980). Since the enzymatic conversion of free cyanide to either formamide or ammonia was not observed in any other plant species, significance of FHL in the metabolism of cyanide by higher plants is questionable (Srivastava and Duvvuru Muni 2010).

\section{Biotransformation of iron cyanides}

If in vivo dissociation of iron cyanides into free cyanide in the absence of light is not prerequisite before uptake by plants, biological fate of iron cyanides is highly dependent on stability and speciation of cyanides present. There are two possible degradation pathways for phyto-assimilating iron cyanides by plants: (1) plants assimilate iron cyanides directly as a substrate through an undefined degradation pathway; (2) iron cyanides dissociates into $\mathrm{Fe}^{3+} / \mathrm{Fe}^{2+}$ and free cyanide first, and then, free cyanide is metabolized by plants through the $\beta$-cyanoalanine pathways (Larsen and Trapp 2006; Miller and Conn 1980). It has been observed that free cyanide did not accumulate in healthy plants (Larsen et al. 2005). When plants were exposed to iron cyanides, amounts of cyanide detected as total cyanide were significantly higher than the background, implying that both iron cyanides were probably still in the same original complexed form in plant materials (Larsen and Trapp 2006; Yu and Gu 2010; Yu et al. $2011 b, 2013)$. Additionally, the enzyme $\beta$-cyanoalanine synthase responsible for phyto-assimilation of free cyanide has been widely observed in different plants. Indeed, activity of $\beta$-cyanoalanine synthase in roots of plants was positively increased with the application of exogenous free cyanide, while slight changes in $\beta$-cyanoalanine synthase were observed in the phyto-treatment amended with ferro- and ferri-cyanide (Yu et al. 2011b, 2012c), indicating that (1) phyto-dissociation of iron cyanides is not a mandatory process involved in phyto-assimilation of iron cyanides; (2) both iron-cyanide species are probably metabolized by plants through an undiscovered degradation pathway rather than the $\beta$-cyanoalanine pathway (Fig. 4).

\section{Phytovolatilization of cyanides}

Although evident for natural release of gaseous cyanide in plants through either ethylene synthesis or hydrolysis of cyanogenic glycosides is very definitive (Peiser et al. 1984; Halkier et al. 1988; Lechtenberg and Nahrstedt 1999; Vetter 2000; Zagrobelny et al. 2004), the amount of gaseous cyanide produced typically maintains at the lowest level due to the innate degradation pathway in plants. Due to the leaf portion being exposed to air, external cyanides 
Fig. 4 Possible mechanism involved in phyto-assimilation of iron cyanides. The dashed line represents the nondefined pathways. Enzyme* refers to nondefined enzymes involved

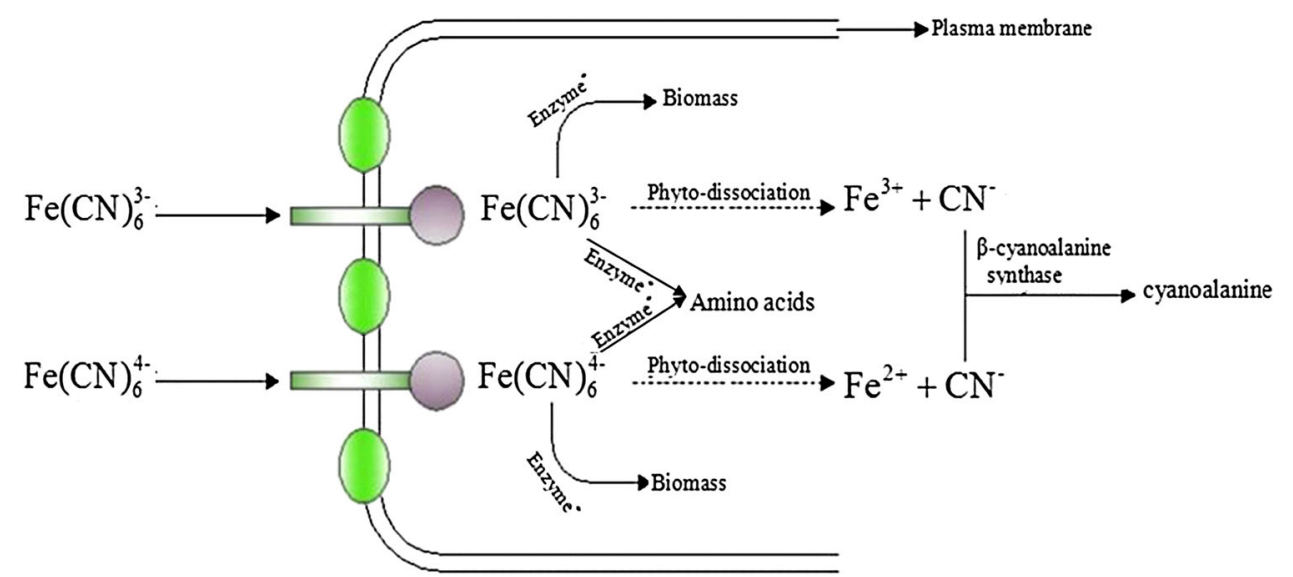

may have transpired through leaves after entering in plant materials. It is evident that cyanide volatilization through plant aerial tissues of transpiration is of minor importance compared with amounts of cyanide metabolized by plants. Indeed, only $1.5 \%$ of the applied cyanide has been trapped in air due to phytovolatilization in basket willows ( $S$. viminalis) (Trapp and Christiansen 2003), while no volatilization of cyanide has been measured in diamond willows (S. eriocephala L. var. Michaux) (Ebbs et al. 2003), weeping willows (S. babylonica L.) (Yu et al. 2007) and pea (Pisum sativum) (Ebbs et al. 2006).

\section{Phyto-benefits of cyanogenic compounds during phytoremediation}

Nitrogen is an essential element for plants, and nitrogenacquisition has become the principal concern for agriculture resulting in reduced crop yields. Ample evidence shows that plants are able to use a wide array of chemical forms, ranging from simple inorganic compounds to polymeric forms (Paungfoo-Lonhienne et al. 2008). Cyanide is a simple nitrogenous compound that arises from both anthropogenic and natural sources (Ebbs et al. 2010). Soil bacteria and fungi have multiple biochemical pathways for degradation and/or assimilation of cyanide (Ebbs 2004), and these organisms may opportunistically use cyanide as a nitrogen source (Ebbs et al. 2010). Indeed, the utilization of free cyanide as an alternate nitrogen source in bacterium Klebsiella oxytoca has been suggested (Kao et al. 2003; Tang et al. 2010). Endogenous cyanogenic glycosides may be utilized as a nitrogen source within plants and as a precursor for amino acid and protein synthesis during seedling development (Niedzwidez-Siegien 1998). Evidence of cyanide metabolism by $\beta$-cyanoalanine synthase is clear (Miller and Conn 1980; Goudey et al. 1989; Maruyama et al. 2001), in which production of asparagine and aspartate associated with cyanide assimilation would provide plants with an additional source of ammonium (Piotrowski et al. 2001; Bruneau et al. 2006; Piotrowski and Volmer 2006; Lea et al. 2007; Ebbs et al. 2010). Several studies have shown that plants are capable of acquiring and assimilating exogenous cyanide (Ebbs et al. 2003; Larsen et al. 2004, 2005; Yu et al. 2004); however, there are no reports that conclusively demonstrate plant's acquisition of exogenous cyanide as an alternate source of nitrogen. Recent works have exhibited much promise in using exogenous cyanide as a nitrogen source for plant nutrition. The enrichment of ${ }^{15} \mathrm{~N}$ from labeled cyanide increased significantly in sorghum (Sorhum bicolor L.) and wheat ( $T$. aestivum L.) when plants were deprived of nitrogen (Ebbs et al. 2010). Nontoxic concentrations of exogenous cyanide as an alternate source of nitrogen for wheat nutrition under nitrogen-limiting conditions have been suggested, where increasing exogenous cyanide alters activity of $\beta$-cyanoalanine synthase and asparaginase (Machingura and Ebbs 2010). Enzymatic assays have showed that free cyanide $(\geq 0.97 \mathrm{mg} \mathrm{CN} / \mathrm{L})$ impaired activity of nitrate reductase significantly in both roots and shoots of rice seedlings (O. sativa $\mathrm{L}$. cv. XZX 45 ), where the effect of cyanide on glutamine synthetase in roots was more evident at $1.93 \mathrm{mg} \mathrm{CN} / \mathrm{L}$ (Yu and Zhang 2012). Rice seedlings grown on $\mathrm{NO}_{3}^{-}$showed significantly higher assimilatory potential for both ferro- and ferri-cyanide than those on $\mathrm{NH}_{4}^{+}$, where conspicuous effects on activity of nitrate reductase and glutamine synthetase in rice seedlings were only observed at the highest concentration of both iron cyanides supplied (Yu et al. 2012d). Although these examples suggest that exogenous cyanide, to a certain level, has a beneficial role in plant nutrition, 
there is still much to be clarified about fate of iron cyanides in plants and contribution of exogenous cyanide to plant nitrogen metabolism.

\section{Conclusion and further perspectives}

While there are natural sources of cyanide, majority that affects the health of the environment is anthropogenic, derived from industrial activities. Phytotoxicity of cyanogenic compounds has been observed at multiple levels, from reduced growth rate to inhibition on enzymatic activities. The toxic properties of free cyanide originate from the action of blocking mitochondrial electron transport system via complexation with iron in terminal cytochrome. Iron cyanides, though less toxic than free cyanide, are potentially hazardous due to release of free cyanide liberated through photodecomposition. Detailed mechanisms involved in phytotoxicity of iron cyanide are still unknown; however, the differential toxicity has been observed, where POD activities and soluble protein content in leaves are the most sensitive indicator for plants exposed ferro- and ferri-cyanide, respectively. Having revised the overall picture of biological fate of cyanogenic compounds, it is clear that in vivo dissociation of iron cyanides into free cyanide in the absence of light is negligible. A number of works have demonstrated that plants are able to readily take up, transport and assimilate different species of cyanides, but with different pathways. Botanical uptake of free cyanide is chiefly achieved by simple diffusion, while a protein-mediated uptake mode has been proposed for phyto-removal of iron cyanide. It is obvious that biological fate of cyanides in plant materials is highly dependent on speciation of cyanides. Degradation of both endogenous and exogenous sources via the $\beta$-cyanoalanine pathway has been widely distributed in higher plants, and the production of asparagine and aspartate associated with cyanide assimilation is suggestive. Because in vivo dissociation of iron cyanides into free cyanide in plant materials is not prerequisite, plants probably metabolized them directly through an undiscovered degradation pathway rather than the $\beta$-cyanoalanine pathway. Assimilation of endogenous cyanide involved in nitrogen metabolism in plants is evident, and phyto-benefits of exogenous cyanide assimilation in plant nutrition are also suggestive; however, there are no reports that conclusively demonstrate plant's acquisition of exogenous cyanide directly as an alternate source of nitrogen. Therefore, more experimental evidence is needed to fully elucidate the detailed degradation pathway of iron cyanides and the potential of cyanogenic compounds as a supplementary source of nitrogen to plant nutrition.
Although this review on cyanogenic compounds in plants has expanded our knowledge to some extent, there is still much more that is not known, and a complete picture of vegetation management for elimination of cyanogenic compounds would require more comprehensive works. One of the future challenges is to continue to clarify the fate and transport of iron cyanides in plants using $\mathrm{N}^{15}$ isotope. The use of $\mathrm{N}^{15}$ labeled ferro- and ferri-cyanide would have resulted in quantitative tracking of the fate of both iron cyanides in plant tissues and would have helped distinguish the difference in the botanical assimilation pathways between the two chemical species of iron cyanides. Another challenge in future research is to elucidate the presence of essential enzymes involved and their expression quantitatively in the assimilation processes of iron cyanides in plants using proteomics or DNA-based molecular analyses. This would provide direct evidence to confirm whether the enzyme $\beta$-cyanoalanine synthase, which is responsible for the degradation of free cyanide in plants, is actually involved in the assimilation of iron cyanides in plants, and subsequently to fully unravel the complete picture of the assimilation pathways of cyanogenic compounds in plants.

Acknowledgments Thanks to Dr. S.-Z. Huang and Mr. Y.-X. Feng in preparation of figures.

\section{References}

Akguc N, Ozyigit I, Yasar U, Leblebici Z, Yarci C (2010) Use of Pyracantha coccinea Roem. as a possible biomonitor for the selected heavy metals. Int J Environ Sci Technol 7:427-434

Ashraf MA, Maah MJ, Yusoff I (2011) Heavy metals accumulation in plants growing in ex tin mining catchment. Int $\mathbf{J}$ Environ Sci Technol 8:401-416

Banerjee AR, Banerjee R, Sharma U (2002) The nitrile-degrading enzymes: current status and future prospects. Appl Microbiol Biotechnol 60:33-44

Barillo DJ (2009) Diagnosis and treatment of cyanide toxicity. J Burn Care Res 30:148-152

Bissey R, Bulter O (1934) Effect of application of sodium chlorate and ammonium thiocyanate on subsequent sowings of wheat. Agron J 26:838-842

Boening DW, Chew CM (1999) A critical review: general toxicity and environmental fate of three aqueous cyanide ions and associated ligands. Water Air Soil Pollut 109:67-79

Briggs GG, Rigitano RLO, Bromilow RH (1987) Physio-chemical factors affecting uptake by roots and translocation to shoots of weak acids in barley. Pestic Sci 19:101-112

Bruneau L, Chapman R, Marsolais F (2006) Co-occurrence of both Lasparaginase subtypes in Arabidopsis: At3g16150 encodes a $\mathrm{K}^{+}$dependent L-asparaginase. Planta 224:668-679

Burken JG, Schnoor JL (1997) Uptake and metabolism of atrazine by poplar trees. Environ Sci Technol 31:1399-1406

Burken JG, Schnoor JL (1998) Predictive relationships for uptake of organic contaminants by hybrid poplar trees. Environ Sci Technol 32:3379-3385

Bushey JT, Ebbs SD, Dzombak D (2006a) Development of a plant uptake model for cyanide. Int J Phytoremediat 8:25-43 
Bushey JT, Small M, Dzombak D, Ebbs SD (2006b) Parameter estimation of a plant uptake model for cyanide: application to hydroponic data. Int J Phytoremediat 8:45-62

Castric PA, Farnden KJF, Conn EE (1972) Cyanide metabolism in higher plants. V. The formation of Asparagine from $\beta$-cyanoalanine. Arch Biochem Biophys 152:62-69

Cheng B, Hu CW, Zhao YJ (2011) Effects of plants development and pollutant loading on performance of vertical subsurface flow constructed wetlands. Int J Environ Sci Technol 8:177-186

Chew MY (1973) Rhodanes in higher plants. Phytochemistry 12:2365-2367

Cohen CK, Fox TC, Garvin DF, Kocian LV (1998) The role of irondeficiency stress responses in stimulating heavy metal transport in plants. Plant Physiol 116:1063-1072

Cooper CE, Brown GC (2008) The inhibition of mitochondrial cytochrome oxidase by the gases carbon monoxide, nitric oxide, hydrogen cyanide and hydrogen sulfide: chemical mechanism and physiological significance. $\mathbf{J}$ Bioenergy Biomemb 40:533-539

Dede G, Ozdemir S, Hulusi Dede O (2012) Effect of soil amendments on phytoextraction potential of Brassica juncea growing on sewage sludge. Int J Environ Sci Technol 9:559-564

Donato DB, Nichols O, Possingham H, Moore M, Ricci PF, Noller BN (2007) A critical review of the effects of gold cyanidebearing tailings solutions on wildlife. Environ Int 33:974-984

Dubey A, Shiwani S (2012) Adsorption of lead using a new green material obtained from Portulaca plant. Int $\mathrm{J}$ Environ Sci Technol 9:15-20

Dzombak DA, Ghosh RS, Young TC (2005) Physical-chemical properties and reactivity of cyanide in water and soil. In: Dzombak DA, Ghosh RS, Wong-Chong GW (eds) Cyanide in water and soil: chemistry, risk, and management. CRC Press, Boca Raton, pp 58-92

Ebbs SD (2004) Biological degradation of cyanide compounds. Curr Opin Biotechnol 15:231-236

Ebbs SD, Bushey J, Poston S, Kosma D, Samiotakis M, Dzombak D (2003) Transport and metabolism of free cyanide and iron cyanide complexes by willow. Plant Cell Environ 26:1467-1478

Ebbs SD, Wong-Chong GM, Bond BS, Bushy JT, Neuhauser EF (2006) Biological transformation of cyanide water and soil. In: Dzombak DA, Ghosh RS, Wong-Chong GM (eds) Cyanide in water and soil: chemistry, risk, and management. CRC Press, Boca Raton, pp 93-122

Ebbs SD, Piccinin RC, Goodger JQD, Kolev SD, Woodrow IW, Baker AJM (2008) Transport of ferrocyanide by two eucalypt species and sorghum. Int J Phytoremediat 10:343-357

Ebbs SD, Kosma D, Nielson EH, Machingura M, Baker AJM, Woodrow IE (2010) Nitrogen supply and cyanide concentration influence the enrichment of nitrogen from cyanide in wheat (Triticum aestivum L.) and sorghum (Sorghum bicolor L.). Plant Cell Environ 33:1152-1160

Ebel M, Evangelou MWH, Schaeffer A (2007) Cyanide phytoremediation by water hyacinths (Eichhornia crassipes). Chemosphere 66:816-823

Eisler R, Wiemeyer SN (2004) Cyanide hazards to plants and animals from gold mining and related water issues. Rev Environ Contam Toxicol 183:21-54

Federico R, Giartosio CE (1983) A transplasmamembrane electron transport system in maize. Plant Physiol 73:182-184

Ghosh RS, Dzombak DA, Luthy RG, Nakles DV (1999) Subsurface fate and transport of cyanide species at a manufactured-gas plant site. Water Environ Res 71:1205-1216

Ghosh RS, Nakles DV, Murarka P, Neuhauser EF (2004) Cyanide speciation in soil and groundwater at manufactured gas plant (MGP) sites. Environ Eng Sci 21(6):752-767
Goudey JS, Tittle FL, Spencer MS (1989) A role for ethylene in the metabolism of cyanide by higher plants. Plant Physiol 89:1306-1310

Halkier BA, Scheller HV, Møller BL (1988) Cyanogenic glucosides: the biosynthesis pathway and the enzyme system involved. In: Evered D, Garnety SF (eds) Cyanide compounds in biology. Wiley, Chichester, pp 49-66

Harada E, Sugase K, Namba K, Iwashita T, Murata Y (2007) Structural element responsible for the Fe(III)-phytosiderophores specific transport by HvYS1 transporter in barley. FEBS Lett 581:4298-4302

Hegazy AK, Abdel-Ghani NT, EI-Chaghaby GA (2011) Phytoremediation of industrial wastewater potentiality by Typha domingensis. Int J Environ Sci Technol 8:639-648

Kang DH, Hong LY, Schwab AP, Banks MK (2007) Removal of Prussian blue from contaminated soil in the rhizosphere of cyanogenic plants. Chemosphere 69:1492-1498

Kao CM, Liu JK, Lou HR, Lin CS, Chen SC (2003) Biotransformation of cyanide to methane and ammonia by Klebsiella oxytoca. Chemosphere 50:1055-1061

Karimi N, Ghaderian SM, Schat H (2013) Arsenic in soil and vegetation of a contaminated area. Int J Environ Sci Technol 10:743-752

Kim SA, Guerino ML (2007) Mining iron: iron uptake and transport in plants. FEBS Lett 581:2273-2280

Kjeldsen P (1999) Behaviour of cyanides in soil and groundwater: a review. Water Air Soil Pollut 115:279-307

Kord B, Mataji A, Babaie S (2010) Pine (Pinus Eldarica Medw.) needles as indicator for heavy metals pollution. Int J Environ Sci Technol 7:79-84

Korte F, Spiteller M, Coulston F (2000) The cyanide leaching gold recovery process is a non-sustainable technology with unacceptable impacts on ecosystems and humans: the disaster in Romania. Ecotoxicol Environ Saf 46:241-245

Larsen M, Trapp S (2006) Uptake of iron cyanide complexes into willow trees. Environ Sci Technol 40:1956-1961

Larsen M, Trapp S, Pirandello A (2004) Removal of cyanide by woody plants. Chemosphere 54:325-333

Larsen M, Ucisik A, Trapp S (2005) Uptake, metabolism, accumulation and toxicity of cyanide in willow trees. Environ Sci Technol 39:2135-2142

Lea PJ, Sodek L, Parry MAJ (2007) Asparagine in plants. Ann Appl Biol 150:1-26

Lechtenberg M, Nahrstedt A (1999) Naturally occurring glycosides. In: Ikan R (ed) Cyanogenic glycosides. Wiley, Chichester, pp 147-191

Ling T, Jun R, Fangke Y (2011) Effect of cadmium supply levels to cadmium accumulation by Salix. Int $\mathrm{J}$ Environ Sci Technol 8:493-500

Machingura M, Ebbs S (2010) Increased beta-cyanoalanine synthase and asparaginase activity in nitrogen-deprived wheat exposed to cyanide. J Plant Nutr Soil Sci 173:808-810

Manar R, Bonnard M, Rast C, Veber AM, Vasseur P (2011) Ecotoxicity of cyanide complexes in industrially contaminated soils. J Hazard Mater 197:369-377

Manning K (1988) Detoxification of cyanide by plants and hormone action. In: Foundation Ciba (ed) Cyanide compounds in biology. Wiley, Chichester, pp 92-110

Maruyama A, Saito K, Ishizawam K (2001) Beta-cyanoalanine synthase and cysteine synthase from potato: molecular cloning, biochemical characterization, and spatial and hormonal regulation. Plant Mol Biol 46:749-760

McMahon-Smith J, Arteca RN (2000) Molecular control of ethylene production by cyanide in Arabidopsis thaliana. Physiol Plant 109:180-187 
Meeussen JCL, Keizer MG, de Haan FAM (1992) Chemical stability and decomposition rate of iron cyanide complexes in soil solutions. Environ Sci Technol 26:511-516

Meeussen JCL, van Riemsdijk WH, van der Zee SEATM (1995) Transport of complexed cyanide in soil. Geoderma 67:73-85

Miller JM, Conn EE (1980) Metabolism of hydrogen cyanide by higher plants. Plant Physiol 65:1199-1202

Mino Y, Ishida T, Ota N, Inoue M, Nomoto K, Takemoto T, Tanaka $\mathrm{H}$, Sugiura Y (1983) Mugineic acid-iron (III) complex and its structurally analogous cobalt (III) complex: characterization and implication for absorption and transport of iron in graminaceous plants. J Am Chem Soc 105:4611-4676

Mudder T, Botz M (2001) A guide to cyanide. Min Environ Manag 9:8-12

Niedzwidez-Siegien I (1998) Cyanogenic glucosides in Linum usitatissimum. Phytochemistry 1:59-63

Pablo F, Stauber JL, Buckney RT (1997) Toxicity of cyanide and cyanide complexes to the marine diatom, Nitzschia closterium. Water Res 31:2435-2442

Parween T, Jan S, Mahmooduzzafar, Fatma T (2012) Evaluation of oxidative stress in Vigna radiata $\mathrm{L}$. in response to chlorpyrifos. Int J Environ Sci Technol 9:605-612

Paungfoo-Lonhienne C, Lonhienne TGA, Rentsch D, Robinson N, Christie M, Webb RI, Gamage HK, Carroll BJ, Schenk PM, Schmidt S (2008) Plants can use protein as a nitrogen source without assistance from other organisms. Proc Natl Acad Sci USA 105:4524-4529

Peiser GD, Wang TT, Hoffman NE, Yang SF, Walsh CT (1984) Formation of cyanide from carbon 1 of 1-aminocyclopropane-1carbonxylic acid during its conversion to ethylene. Proc Natl Acad Sci USA 81:3059-3063

Piotrowski M, Volmer JJ (2006) Cyanide metabolism in higher plants: cyanoalanine hydratase is a NIT4 homolog. Plant Mol Biol 61:111-122

Piotrowski M, Schonfelder S, Weiler EW (2001) The Arabidopsis thaliana isogene NIT4 and its orthologs in tobacco encode betacyano-L-alanine hydratase/nitrilase. J Biol Chem 276:2616-2621

Poulton JE (1990) Cyanogenesis in plants. Plant Physiol 94:401-405

Rennert T, Mansfeldt T (2002) Sorption of iron-cyanide complexes on goethite in the presence of sulfate and desorption with phosphate and chloride. J Environ Qual 31:745-751

Roustan JL, Sablayrolles JM (2003) Feasibility of measuring ferricyanide reduction by yeast to estimate their activity during alcoholic fermentation in wine-making conditions. J Biosci Bioeng 96:434-437

Samiotakis M, Ebbs SD (2004) Possible evidence for transport of an iron cyanide complex by plants. Environ Pollut 127:169-173

Schnepp R (2006) Cyanide: sources, perceptions, and risks. J Emerg Nurs 32:S3-S7

Shirai R (1978) Study on cyanide metabolizing activity in mesocarp of Rosaceae. J Coll Arts Sci Chiba Univ B-11

Shirai R, Kurihara T (1991) Distribution of rhodanese in plants. J Plant Res 104:341-346

Siedow JN, Umbach AL (1995) Plant mitochondrial electron transfer and molecular biology. Plant Cell 7:821-831

Solmonson LP (1981) Cyanide as a metabolic inhibitor. In: Vennesland B, Conn EE, Knowles CJ, Westley J, Wissing F (eds) Cyanide in biology. Academic Press, London, pp 11-28

Sreekanth TVM, Nagajoythi PC, Lee KD, Prasad TNVKV (2013) Occurrence, physiological responses and toxicity of nickel in plants. Int J Environ Sci Technol 10:1129-1140

Srivastava AC, Duvvuru Muni RE (2010) Phytoremediation of cyanides. In: Ashraf M (ed) Plant adaptation and phytoremediation. Springer Science+Business Media B.V., Berlin, pp 399-424
Tang P, Hseu YC, Chou HH, Huang KY, Chen SC (2010) Proteomic analysis of the effect of cyanide on Klebsiella oxytoca. Curr Microbiol 60:224-228

Theis TL, Young TC, Huang M, Knutsen KC (1994) Leachate characteristics and composition of cyanide-bearing wastes from manufactured gas plants. Environ Sci Technol 28:99-106

Tomati U, Federici G, Cannella C (1972) Rhodanese activity in chloroplasts. Physiol Chem Phys 4:193-196

Trapp S, Christiansen H (2003) Phytoremediation of cyanide-polluted soils. In: McCutcheon SC, Schnoor JL (eds) Phytoremediation: transformation and control of contaminants. Wiley, Hoboken, pp 829-862

Trapp S, McFarlane C, Matthies M (1994) Model for uptake of xenobiotics into plants: validation with bromacil experiments. Environ Toxicol Chem 13:413-422

Trapp S, Larsen M, Pirandello A, Danquah-Boakye L (2003) Feasibility of cyanide elimination using plants. Eur J Miner Proc Environ Protect 3:128-137

Vetter J (2000) Plant cyanogenic glycosides. Toxicon 38:11-36

Wagner AM, Krab K (1995) The alternative respiration pathway in plants: role and regulation. Physiol Plant 95:318-325

Wallace A, Cha JW, Mueller RT (1977) Cyanide effects on transport of trace materials in plants. Commun Soil Sci Plan 8:709-715

White DM, Pilon TA, Woolard C (2000) Biological treatment of cyanide containing wastewater. Water Res 34:2105-2109

Wong-Chong GM, Ghosh RS, Bushey JT, Ebbs SD, Neuhauser EF (2006) Natural sources of cyanide. In: Dzombak DA, Ghosh RS, Wong-Chong GM (eds) Cyanide in water and soil: chemistry, risk, and management. CRC Press, Boca Raton, pp 25-40

Yngard R, Damrongsiri S, Osathaphan K, Sharma VK (2007) Ferrate (VI) oxidation of zinc-cyanide complex. Chemosphere 69:729-735

Yu XZ, Gu JD (2007) Difference in Michaelis-Menten kinetics for different cultivars of maize during cyanide removal. Ecotoxicol Environ Saf 67:254-259

Yu XZ, Gu JD (2009) Uptake, accumulation and metabolic response of ferricyanide in weeping willows. J Environ Monit 11:145-152

$\mathrm{Yu} \mathrm{XZ,} \mathrm{Gu} \mathrm{JD} \mathrm{(2010)} \mathrm{Effect} \mathrm{of} \mathrm{temperature} \mathrm{on} \mathrm{removal} \mathrm{of} \mathrm{iron}$ cyanides from solutions by maize plants. Environ Sci Pollut Res 17:106-114

Yu XZ, Zhang FZ (2012) Activities of nitrate reductase and glutamine synthetase in rice seedlings during cyanide metabolism. J Hazard Mater 225-226:190-194

Yu XZ, Zhang FZ (2013) Effects of exogenous thiocyanate on mineral nutrients, antioxidative responses and free amino acids in rice seedlings. Ecotoxicology 22:752-760

Yu XZ, Trapp S, Zhou PH, Wang C, Zhou XS (2004) Metabolism of cyanide by Chinese vegetation. Chemosphere 56:121-126

Yu XZ, Trapp S, Zhou PH (2005a) Phytotoxicity of cyanide to weeping willow trees. Environ Sci Pollut Res 12:109-113

Yu XZ, Zhou PH, Zhou XS, Liu YD (2005b) Cyanide removal by Chinese vegetation: quantification of the Michaelis-Menten kinetics. Environ Sci Pollut Res 12:227-232

$\mathrm{Yu} \mathrm{XZ,} \mathrm{Gu} \mathrm{JD,} \mathrm{Liu} \mathrm{S} \mathrm{(2007)} \mathrm{Biotransformation} \mathrm{and} \mathrm{metabolic}$ responses of cyanide in weeping willows. J Hazard Mater 147:838-844

Yu XZ, Gu JD, Li L (2008) Assimilation and physiological effects of ferrocyanide on weeping willows. Ecotoxicol Environ Saf 71:609-615

Yu XZ, Li F, Li K (2011a) A possible new mechanism involved in ferro-cyanide metabolism by plants. Environ Sci Pollut Res 18:1343-61350

Yu XZ, Peng XY, Wang GL (2011b) Photo-induced dissociation of ferri- and ferro-cyanide in hydroponic solution. Int J Environ Sci Technol 8:853-862 
Yu XZ, Zhang FZ, Li F (2012a) Phytotoxicity of thiocyanate to rice seedlings. Bull Environ Contam Toxicol 88:703-706

Yu XZ, Li F, Li K (2012b) Effects of pH on ferri-cyanide uptake and assimilation by several plants. Int $\mathrm{J}$ Environ Sci Technol 9:227-233

Yu XZ, Lu PC, Yu Z (2012c) On the role of $\beta$-cyanoalanine synthase (CAS) in metabolism of free cyanide and ferri-cyanide by rice seedlings. Ecotoxicology 21:548-556

Yu XZ, Sheng PP, Gu JG, Zhou Y, Zhang FZ (2012d) Evidence of iron cyanides as supplementary nitrogen source to rice seedlings. Ecotoxicology 21:1642-1650

Yu XZ, Zhang FZ, Peng XY (2013) Effects of inhibitors on ferricyanide uptake and assimilation by plants. Int $\mathrm{J}$ Environ Sci Technol 10:125-132
Zagrobelny MBS, Rasmussen AV, Jørgensen B, Naumann CM, Møller BL (2004) Cyanogenic glucosides and plant-insect interactions. Phytochemistry 65:293-306

Zagury GJ, Oudjehani K, Deschenes L (2004) Characterization and availability of cyanide in solid mine tailings from gold extraction plants. Sci Total Environ 320:211-224

Zheng A, Dzombak DA, Luthy RG (2004) Effects of thiocyanate on the formation of free cyanide during chlorination and ultraviolet disinfection of publicly owned treatment works secondary effluent. Water Environ Res 76:205-212 